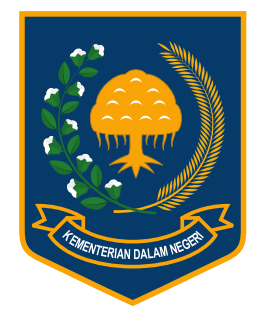

Jurnal Bina Praja 8 (1) (2016): 121-133

Jurnal Bina Praja

e-ISSN: 2503-3360 | p-ISSN: 2085-4323

Accreditation Number

735/AU2/P2MI-LIPI/04/2016

http://jurnal.kemendagri.go.id/index.php/jbp/index

\title{
INTERGOVERMENTAL COOPERATION INITIATIVE ON SUSTAINABLE TRANSPORTATION MANAGEMENT IN JABODETABEK
}

\author{
Hidayat Chusnul Chotimah ${ }^{1, *}$ \\ ${ }^{1}$ Postgraduate International Affairs Gadjah Mada University (UGM) \\ Jl. Sosio-Justisia No. 1 Bulaksumur, Yogyakarta 55281, Indonesia
}

Received: 28 February 2016; Accepted: 7 May 2016; Published online: 31 May 2016

\begin{abstract}
The main issues in Jabodetabek concerning the management of transportation are related to the increased use of private vehicles and the decreased use of public transportation, overcrowding daily traffic in Jabodetabek, the high congestion followed by insecurity in traffic, environmental pollution, uncontrolled growth of and underdeveloped infrastructure, and irregularities in land use. To overcome these problems, sustainable transportation management becomes very important in which the government should be able to cope with environmental, economic and social factors under the decision making related to transportation in Jabodetabek. Therefore, through interactive planning, this study will examine intergovernmental cooperation initiatives on sustainable transportation management in Jabodetabek. This study uses qualitative and descriptive method through literature study and existing statistics as the resources to apply the interactive planning approach. The result shows that there are found a number of problems and gaps in the management of transportation in Jabodetabek that needs to be reduced because it has the same scope of other gaps. From these problems can be made further action programs and policies in accordance with the resources owned, and then, the design of implementation made and controlled whether in accordance with the purpose or not. Thus, sustainable transportation management in the Jabodetabek needs to be done jointly in an institutional or policy framework involving governments Jabodetabekpunjur, BKSP Jabodetabekpunjur, and the private sector.
\end{abstract}

Keywords: intergovernmental cooperation, transportation, sustainable transportation, interactive planning.

\section{INTRODUCTION}

Indonesia is one country in Asia that is experiencing growth in urban population so rapidly. In 2010, Indonesia's population living in urban areas has reached 118 million or $49.8 \%$ of the entire population of Indonesia. The figure is very prominent, by comparing with the condition in 1950 that was only about $12.4 \%$ of the population living in urban areas. A symptom of urban population growth was then followed by the rapid growth of suburbs known as suburbanization process that led to the physical expansion of urban areas at random/ dispersal (urban sprawl) (Mungkasa, 2012). Jakarta as a metropolitan city in Indonesia has experienced increasingly large settlement densification and the higher population in peri-urban areas of Jakarta where the most significant population growth occurred in the 1980-1990 period with a growth rate of 2.4 percent, while in the surrounding great cities were of 2.7 percent (Devira 2008 in Mungkasa, 2012). This condition is a consequence of the pursuing of social and economic services as well as a better livelihood, which is further supported by the ease of accessibility through the development of road infrastructure. As a result, urbanization to peri-urban areas of Jakarta is increasing (Zulkaidi et al 2007 in Mungkasa, 2012). On the other hand, an increase in economic growth in urban areas has increased the role of the transportation sector in supporting the achievement of development goals and results. The function of the transportation sector will stimulate increased economic development since between the function of the transport sector and economic development has a causal relationship (reciprocal).

Meanwhile, transportation activities have also produced more than $23 \%$ of total greenhouse gas emissions arising from the combustion of fuel. At least the emissions resulting from transportation activities in the world is $26 \%$ from the use of fuel (Kahn, 2007). The transportation sector also uses between $25 \%$ and $60 \%$ of land in major cities

\footnotetext{
* Corresponding Author

Phone : +6287848494660

Email : hidayat.chusnul@gmail.com
} 
around the world (Litman and Burwell, 2006) causing the capacity of land use for other activities reduced. On the other hand, the expansion of land for the use of transportation infrastructure that has been done has still not overcome the problem of traffic congestion in major cities. This then led to an impact on the time lost in traffic jams in some countries that also caused economic losses of about 1 to 3\% of Gross Domestic Product (GDP) (Gwilliam, 2002). Meanwhile, more than one million people died and 3 million injured every year in road traffic accidents (WHO, 2004), even these accidents result in economic costs about $5 \%$ of GDP in some countries.

Even so, transportation employs about 3 percent to 7 percent of the workforce. It can be seen from several countries such as the Republic of Korea, for example, where more than one million people are employed in the transportation sector from the economically active population of 23.8 million, which is 4.3 percent. The percentage is likely higher in developing countries, including in Indonesia where the restructuring and rationalization of the sector still have not been done extensively (UNESCAP, 2008). Moreover, Indonesia still faces a large gap between transportation infrastructure and one way to reach this gap is through low-emission public transport (low-emission public transport). Meanwhile, if the public transport development model is chosen as the main part of the structure of urban transport, there will be no trade-off between low-emission transport sectors with rapid growth. Hong Kong is an example of a metropolis which has maintained high mobility by combining various modes of public transport instead of concentrating only on the road sector alone (Research and Development Agency of Transportation, 2015).

The provision of transportation modes eventually must pay attention to the concept of sustainable development given that the impact of the use of transportation modes, namely of carbon emissions produced may threaten the safety of the public at large. Based on the concept of sustainable development, the human need to use the resources available to meet their needs as far as the use does not harm the needs of future generations (Litman and Burwell, 2006). Therefore, Litman and Burwell (2006), mentions the main principles of sustainable transportation is that the government must address the environmental, economic and social factors in their transportation decisions. Another opinion, as Gudmundsson \& Hojer (1996), stated that there are four key elements to the concept of sustainable development for transportation, namely the protection of natural resources, capital maintenance of intergenerational production, the drive for the increase and equalization of life quality. While the approach of Black (2010) and the Buehler \& Pucher
(2011) stated that a sustainable transportation system is one that provides transportation and mobility of renewable energy sources, thereby minimizing emissions locally and globally, to prevent deaths and injuries from road traffic accidents and minimize loss of economic productivity due to traffic congestion.

In Handbook Module 5e: Transport and Climate Change (EM T 2004 in Sakamoto, Belka and Metschies, 2011), a sustainable transportation system is one that:

1. Allows individuals, companies, and communities to meet their basic mobility needs by protecting ecosystems and human health, and to promote equality within and among the next generation;

2. Affordable, efficient, offers choice of transportation modes, and supports a competitive economy, as well as balanced regional development; and

3. Reducing emissions and waste within the threshold limits of the environment, using renewable resources at or below the rate of rising (suppletion), and the use of nonrenewable resources at or below the level of development of renewable replacement resources, while minimizing the impact of land use and the level of noise.

Meanwhile, A.R. Barter Tamim Raad in his book Taking Steps: A Community Action Guide to People-Centred, Equitable, and Sustainable Urban Transport stated that a sustainable transportation system must have the principles of accessibility, social equality, environmental sustainability, health and safety, public participation and transparency, low cost and economical, information, advocacy, capacity building for policy makers, as well as networking.

From the explanation, the author intends to examine transportation management in a sustainable manner through cooperation between regions in Jabodetabek so that its negative impacts can be minimized. This is because the accumulated problems of congestion and other transportation problems, especially in Jakarta, demand a settlement of Jakarta Provincial Government on the mobilization of the population who generally come from cities around Jakarta who every day have to do their activity in Jakarta (Raharjo, 2009). Thus, the solution in the procurement of transportation is not only the responsibility of Jakarta City Government but also other city governments such as Bogor, Depok, Tangerang and Bekasi require transportation management on an ongoing basis through the interregional cooperation so as to provide a positive impact or greater benefit.

In the most basic sense, inter-regional cooperation itself can be defined as the relationship 
between the government as mentioned by William Anderson (1960), which defines it as an important agency of an activity or interaction between governmental units of all types and levels. Other opinions such as Ansell and Gash (2007) described the cooperation between the regions in terms of collaboration as an arrangement set up where one or more public agencies directly involve actors and non-state actors in the process of formal collective decision-making, consensus-oriented, and deliberation and that aims to create or implement public policy or manage public program or assets. That definition emphasizes on six essential criteria which consist of (1) the forum is initiated by public officials or public institutions, (2) the forum participants include non-state actors, (3) the participants are directly involved in decision-making and not just consulting with public officials, (4) the forum is formally organized and meet collectively, (5) the forum aims to make decisions by consensus (even if consensus is not achieved in practice), and (6) the focus of the collaboration is on public policy or public management.

Meanwhile, according to Bingham and O'Leary (2006) there are two collaborative dimensions in government relation and cooperation that can be intermittent, temporary, or permanent; and can take the form of formal coordination, partnerships, coalitions, or formal network. Furthermore, areas of cooperation among local governments are associated with improved public services, border areas, spatial, disaster management and handling of potential conflicts, increasing the role of provinces, the issue of regional division, and the issue of poverty and regional disparity reduction (Tarin, 2009).

A cooperation between regions can run in accordance with plans that have been developed through collective action just as the opinion Feiock (2004) which describes the cooperation through institutional collective action (ICA) can generate coordination of metropolitan government, in the best provision given in full about how or under the conditions of governance cooperation that may arise. ICA focuses on how local government officials understand and consider the costs and benefits of cooperation to contemplate long-distance service agreements and other forms of collaboration among government (Feiock, 2007).

Meanwhile, the motivation for the government to cooperate in the provision and delivery of services as described by Feiock (2007) includes an explanation based on the collective benefits in public interests and private interests based on economic or political opportunism of local actors. According to Feiock (2007), long-distance collaboration agreement produces collective benefits through production efficiencies and economic scale in the provision and production of services and to internalize spillover problems.

In the case of inter-regional cooperation, Jabodetabek, in fact, has their institutional host, namely BKSP (Agency for Development Cooperation) of Jabotabek (Jabodetabek now). BKSP was established by the Governments of DKI Jakarta and West Java province in 1976 and renewed in regulation with the Governors of DKI Jakarta, West Java, and Banten as well as the Regents/Mayors in Jabodetabek and Cianjur in 2006 as an effort to revitalize the BKSP (Ruyani 2011). BKSP is actually expected to serve as a forum for communication between the provincial and district/city governments in Jabodetabek. The problem is that this institution actually does not have sufficient authority to implement development in Jabodetabek because its authority is still at the respective provincial government and district/ city governments. Another issue such as financial problem is also a reason of BKSP not progressing because everything is still very dependent on resources allocated by the Governments of DKI Jakarta, West Java, and Banten so that BKSP Jabodetabek's role becomes less effective (Secretary of BKSP, 2008).

As in a study conducted by Abdurahman (2008) who found the issue related to the series of Central and Provincial Government's role in determining the policy of cooperation in which the regionalization of Jabodetabek is administratively top-down pattern planning began moving towards the bottom-up pattern. Although the policy of participation for each Autonomous Region (DKI Jakarta and the related surrounding Regency/ City) has been established, but according to the findings of Abdurahman (2008) the lack of active participation of legislative and public components, as well as management professionals component in conducting cooperation, exposes weaknesses of this conception. Here Abdurahman (2008) mentioned that the weakness of understanding is reflected in the concepts used in Jabodetabekjur cooperation, especially since the implementation of the Law on Regional Autonomy which application was started in 2001. The inability of the replacement of structural colors is full with non-structural patterns in accordance with the procedure reference of regional cooperation i.e. Government Regulation No. 50 Year 2007 becomes the reason of the ineffectiveness of such cooperation. This is because the previous action confused the policy platform which has structural implementation consequences with the product of non-structural policy (Abdurahman, 2008).

Not surprisingly that there is a discourse about the plan on BKSP dissolution stated by the Jakarta Provincial Government for it does not have a strategic benefit for the three provinces that has 
made up a collective agreement in the cooperation. This assumption is justified because BKSP has no binding authority for the members and is incapable of uniting the existing spatial plan in three provinces, including in the management of transportation (Gatranews, Online Issue 12 November 2015). Some of the problems in the management of transportation in the Jabodetabek can be formulated as follows.

1. Increase in the use of private vehicles and decrease in the use of public transportation. The growth of private vehicles in urban is increasing, while capital shares of public transportation from year to year tend to decline, in 2002 the use of public transportation was to $55 \%$ and it decreased significantly until 2010 to 28\% (Research and Development Agency of Transportation, 2015)

2. Daily traffic in Jabodetabek is constantly increasing due to the pressure of trips towards the city center of Jakarta. It happens every day with the highest loads occur at peak hours in the morning and afternoon. Approximately 7.70 million trips per day in and out of Jakarta from Tangerang, Bogor, Depok and Bekasi in 2004 and with trips growth rate forecast of $3-4 \%$ per year, then in 2014 the number of trips reached 10.86 million trips. The workers who travel daily or commonly called the commuters or commuting. In 2010, the number of commuters from Bodetabek to Jakarta reaches 1.5 million commuters per day. During the day, the population of Jakarta reached 12.1 million people (9.6 million of Jakarta residents and 2.5 million of commuters) (Final Draft of Jakarta RPJMD in 2013-2017).

3. The high congestion and low levels of security and safety in traffic. Congestion happens to the borders have already penetrated into the inner circumference area of Jakarta (Inner Ringroad). It is characterized by waiting time off from the main intersection that reached more than 10 minutes per intersection. One of the factors that cause congestion in Jabodetabek is the volume of vehicles. This is because of population growth in urban areas is not directly proportional to the availability of land, thereby causing the tendency of society to buy land for their resettlement outside Jakarta which is relatively cheaper price and still spacious. The emergence of new cities outside Jakarta that are spreading (sprawling), aggravating the traffic in Jakarta because many people who work in Jakarta but live outside Jakarta such as in Depok, Bogor, Bekasi, and Tangerang using their private vehicles to get to the office (Research and Development Agency of Transportation, 2015).

4. The increase of environmental pollution. The development of the land at that time was not controlled (land speculators, idle land, lack of control of the spatial, too many permits on the development of land issued) and brought many environmental problems (excessive extraction of ground water, pollution, reduction of open green spaces, and water catchment areas) and congestion problems. At the peak of the property boom of the ' 90 s, there were 23 new towns in the area of 500-6000 ha developed around Jakarta (Firman, 2004; Winarso and Firman, 2002 in Research and Development Agency of Transportation, 2015).

5. The uncontrollable growth of facilities and the backwardness of infrastructure development, which can be seen in the development of uncontrolled construction, especially the construction going across the regions which have relevance to the function and structure of Jakarta city.

6. The deviation of land use. Data shows there has been an increased use of land in Jabodetabek in 1992 and 2001 by $10 \%$ for settlements. At the same time, there has been a reduction in the extent of protected areas up to $16 \%$. So overall there are deviations of $20 \%$ towards the direction of land use in Jabodetabek Area Spatial Planning. Meanwhile, for the Bopunjur Region which is upstream of Jabodetabek area, based on Landsat imagery in 2001 there has been a deviation of land use amounted to 79.5\% from the direction set out in Presidential Decree No 114 of 1999. This is caused by the growth of residential/urban areas quite rapidly with an area of 35,000 ha or $29 \%$ of total area of Bopunjur Region (Research and Development Agency of Transportation, 2015).

Considering the complexity of the problems in the management of transportation that can not be separated from the spatial arrangement in Jabodetabek then the cooperation sustainability between regions in Jabodetabek through BKSP should continue. Sustainability of this cooperation should be accompanied with the improvement of institutional structural issues related to the problem of authority in BKSP body itself. Interregional cooperation in the management of transportation is very important especially in creating sustainable transportation for a variety of existing problems that have spread to various aspects including environmental issues and public or Jabodetabek residents' health issues. Therefore, this paper will analyze the interactive planning that can be applied in the cooperation of sustainable transportation management in Jabodetabek. As a result, it can then provide solutional feedback on the issues of transportation management in the region. 


\section{Method}

This study uses qualitative method through interactive planning approach. The analysis technique used in this research is descriptive intended to describe the situation, facts, and events systematically. Nawawi and Martina (1994) mentioned that the descriptive qualitative study is conducted by collecting data in reasonable circumstances, use a systematic, focused, and accountable way of work so it does not lose its scientific nature. While data collection technique used in this research is through literature review and existing statistics, derived from the results of the study, research, or official reports from the relevant agencies as well as previous studies to analyze documents and secondary data as an ingredient in interactive planning methods. Interactive planning as a methodology id derived from the concept interactivism and is a participatory method of dealing with a series of problems and intertwined when it is believed that if an act is not done, then the desired future is unlikely to happen and that if action is taken properly, the possibility of the desired future can be realized (Ackoff, 1981 in Lumbo, 2007: 15). Ackoff (2001) explained that the design in interactive planning consists of:

1. formulating the mess, where the organization will be faced with a set of interactions between threats and opportunities, or a problem system called "mess". Identification of this activity is to provide a focus for further planning by identifying what to avoid all risks that may arise and involve some preparation for the future (Ackoff, 2001: 5). In this study, formulating the mess is used to identify gaps and problems of transportation in Jabodetabek.

2. ends planning, which is a planning process intended to eliminate or reduce the gap which taken collectively and interactively. This stage is a way to eliminate the gap that is similar or within the same scope and sector to another gap in Jabodetabek transportation problems that have previously been identified in formulating the mess.

3. means planning, which is an act of determining what should be done in selecting or creating action programs, practices, projects, programs, and policies to be implemented in redesigning the ideal organization. Therefore, this stage is used to redesign the institutional form of BKSP as an agency or institution that previously not functioning as it should and in need to adapt to new action programs or policies to support sustainable transportation cooperation initiative in Jabodetabek.

4. resource planning, which consists of: (1) how much of each type of facilities and equipment,

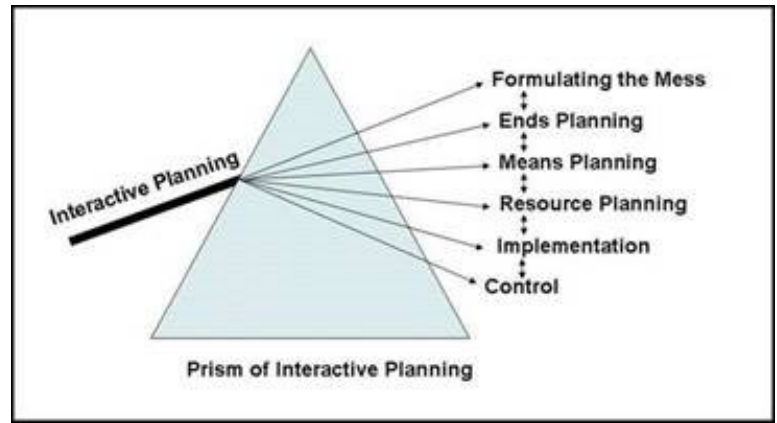

Figure 1. Prism of Interactive Planning Source: Ackoff (2011)

materials, energy, and services; personnel, money; and information, knowledge, understanding, and wisdom that will be required; when and where, and for what purpose and what is the right way to choose; (2) how much of each kind of resource will be available and placed at the desired time if without planning intervention. (3) What to do about deficiencies or excesses that have been identified. This stage serves to see what resources in Jabodetabek that must be met to implement the action programs and policies designed to support sustainable transportation cooperation initiatives in Jabodetabek.

5. design of implementation, which is part of the planning design done to determine who is doing what, where, and when. By looking at the problems of transportation in Jabodetabek that have previously been identified then this stage is used in terms of the sustainable transportation policy setting and the implementation of cooperation by the actors involved in Jabodetabek.

6. design of controls, which explains how the monitoring of tasks and the schedule and adapt to the failure to meet the schedule, and how to monitor the decision of planning implementation to determine whether the result determined is in accordance as expected or not, and if not, determine the corrective action that should be taken to deal with it. This stage is used to control the implementation of policies and programs that have been designed whether in compliance with the achievement of objectives in cooperation initiatives of sustainable transportation management in Jabodetabek or not.

Seeing really complex problems in Jabodetabek transportation in which the existing problems are not only related to the transportation system or institutions that govern their cooperation but also involve financial issues and actors that need to be involved in creating sustainable transportation 
cooperation in the Jabodetabek. Thus, the stages of interactive planning are very helpful to overcome the complexity of the problem. Overall, the interactive planning part can be illustrated in Figure 1.

To support the planning in interactive planning method, according to Ackoff (2001) there are several principles that need to be considered as follows.

\section{1) Participative principle:}

All stakeholders participate in all stages of the planning process and understand the role each with the collateral of "objectivity". While the role of professional planners is not to plan but to help stakeholders to make plans for themselves.

\section{2) Continuity principle:}

Because the changes values and unexpected events occur, then the plan needs to be constantly updated.

\section{3) Holistic principle:}

The importance of interaction between one system component with other system components so that it encourages to get together and have a mutual dependence in planning many components or levels of the organization.

Through interactive planning method, cooperation in the management of sustainable transportation in Jabodetabek can be performed as a method that helps in making policies and plans related to the management of transportation. By identifying the existing problems and formulating the actions that need to be done, of course, these are expected to provide benefits for the actors involved in it. Interactive planning method also gives an overview of how the interrelationship between the stages that exist can provide a solution for carrying out the actions that need to be carried out in cooperation between regions in Jabodetabek so that cooperation between regions in Jabodetabek will also provide the benefits and positive impact on each of the region in accordance with the characters of the concerning region.

\section{RESULT AND DISCUSSION}

\section{A. The Needs for Sustainable Transportation Management in Jabodetabek}

So far, the problems in the development of sustainable of transportation are associated with the development of the region that should be integrated with the development of transportation networks. Between planning for regional development and the development of transportation systems are interacting and influencing. The regional development in an area will create or cause new transportation system, and vice versa, the making of transportation networks will trigger the growth in developed regions. In this case, much needed a development in an integrated manner, both the new residential areas as well as the transportation network and its mode, so that each will not "run wild". Learning from the experience in Jakarta ten years ago, the development of the region tend to be highly dispersive (spread) in the suburban areas, the impact even reached the neighboring cities. Since the transportation system was not also being developed (or developed but not as fast as the growth of regional development) then there is the increased length of traffic jams, not only in Jakarta but also in suburban areas. To that end, cooperation between regions, especially in Jabodetabek area is very important in the management of integrated transportation, which is based on applicable policies and regulations to carry out such cooperation.

Interregional cooperation is formally regulated in Law No. 32 Year 2004 on Regional Government Article 87 paragraph (1) which states that some regions may enter into interregional cooperation governed by a joint decision, (2) a region can form interregional cooperation agency, (3) a region can collaborate with other agencies governed by a joint decision, (4) a joint decision and/or cooperation agency as referred to in paragraph (1), paragraph (2), paragraph (3), (4) which burden the society and the region must be approved by regional parliament (DPRD). Meanwhile, the implementation of the cooperation policy is stipulated in Government Regulation No. 50 of 2007 on the procedure for the implementation of regional cooperation. The implementation of inter-regional cooperation will be created if awareness among their respective regions to cooperate and coordinate arose. Furthermore, the decision to work together requires participation persuasion or partnership that will be mutually beneficial and/or for a greater purpose (Keast et al., 2007).

Looking at the regional spatial planning of Jabodetabek, transportation management needs to get more attention and requires the support of interregional cooperation in the region. It is based on problems experienced related to the management of transportation that has long been planned but did not provide the right solutions for the problems that exist. Various problems such as traffic congestion, air pollution, economic activity and the production, and population densities continue to increase due to urbanization, has worsened the situation and condition of spatial planning that is increasingly chaotic in Jabodetabek.

Another issue that is equally important is the public transportation facilities that are currently dominated by bus and microbus and are considered less comfortable, less safe and less efficient. Meanwhile, mass transportation (mass rapid transit) such as the train is actually indeed been provided, but still unable to address the issue of 
traffic congestion. The users of public transportation service in this regard are limited to the lower and middle classes since the suit-and-tie people are still reluctant to use public transportation for the reason of the public transportation comfortability that is considered too low compared to a private vehicle that is so comfortable with door to door service. Therefore, the prolonged queues and traffic jams on each corridor and downtown, and as a result of the massive redundancies of energy fuel and air pollution, become the daily menu of urban trip makers (Munawar, 2007).

Actually, during the Dutch colonial government, in an article by Giebels entitled "An IndonesianDutch Concept on Metropolitan Planning of the Region of Jakarta" (in Nas, 1986) mentioned the intention of developing the concept of Jabodetabek that adopted the concept of "bundled deconcentration". Meanwhile, the idea of unification of Jakarta, Bogor, Depok, Tangerang, Bekasi and Cianjur (Jabodetabekjur) in one functional urban area was first coined officially by President Sukarno in 1965 that instructed the Directorate of City and Regional Planning to draw up the Master Plan of Jakarta and its surrounding. The regulation related to the unification of the region, has been created in line with regional development and dynamics of Jabodetabekjur, but the development of the region was faster than the effectiveness of the regulation to regulate it, thus causing the gap between the object to be regulated and the instruments that govern it (Research and Development Agency of Transportation, 2015).

In viewing Jabodetabek as a metropolitan area, there is a difference of views between regional provincial governments of Jabodetabekjur. West Java Provincial Government considered that the problems in Jabodetabek were derived from service functions of the surrounding areas to Jakarta. In connection with that, the province of West Java deemed it necessary to make a breakthrough, among other, by drafting the concept of 'Twin Metropolitan Jakarta and BodebekKarpur' (Bogor-Depok and Bekasi, Karawang, Purwakarta), which developed independently. Meanwhile, the province of Banten expected a growth in the area of Tangerang that is independent with a successful settlement, which means an independent city accompanied by the growth of opportunities for independent business, work, and decent life so that it does not depend on Jakarta. (PRPW UI, 2013 in Research and Development Agency of Transportation, 2015).

Presidential Regulation No. 54 of 2008 on Spatial Planning in the Regions of Jakarta, Bogor, Depok, Tangerang, Bekasi, Puncak and Cianjur (Jabodetabekpunjur) has harmonized spatial planning in Jabodetabekjur, but has not been effectively mitigate environmental problems and harmonize the development of rapidly growing settlements since the presidential regulation has not been implemented consistently and accurately (PRPWUI, 2013 in Research and Development Agency of Transportation, 2015). Presidential Regulation No. 54 of 2008 is based on the scope of the functional region, which is divided into three provinces, which consists of 15 Districts and Cities. On the other hand, the autonomous authority of local government covered has a different position in Jakarta, which lies in the provincial government, while in the other two provinces lies in districts and cities. This leads to consequences on the coordination function and different authority, which led to the ineffectiveness of the existing cooperation agency (Research and Development Agency of Transportation, 2015). Therefore, to identify the existing problems and then determine further the action to tackle the various problems that arise in such cooperation, the following is a model of interactive planning in cooperation of Jabodetabekpunjur.

\section{B. Interactive Planning Model in Sustainable Transportation Management Cooperation}

Transportation development goes hand in hand with the development of economic activity and a combination of three factors of production: land, labor, and capital as well as with regard to human satisfaction of geographical position change of people or goods (Banister, 1995 in Mansyur, 2008). Meanwhile, socio-economic problems in transportation system are characterized by inequality in access for people and goods for present and future generations (Sterner, 2003 in Mansyur, 2008). As the impact, the interaction between spatial planning and dynamic and complex transportation, through a proper transportation system, will provide positive and negative impacts or externalities (Mansyur, 2008: 12). Therefore, the selection of interactive planning method is conducted to help determine the decision-making action in sustainable transportation management cooperation in Jabodetabek so that it is expected to be able to give positive impact to the relevant government as well as the society. Below is the interactive planning table thatconsists of formulating the mess, ends planning, means planning, resources planning, design of implementation and design control stages.

Based on Table 1, already known the problems related to institutional cooperation and transportation management in formulating the mess. Once formulating the mess is identified, then the next stage is to do the ends planning of some existing gaps by reducing some of the gaps, namely: 
Table 1.

Interactive Planning Stages in Sustainable Transportation Management Corporation

\begin{tabular}{|c|c|}
\hline \multirow{9}{*}{ Formulating the mess } & $\begin{array}{l}\text { The growth of private vehicles in urban areas has increased and the use of public } \\
\text { transport has decreased significantly }\end{array}$ \\
\hline & The increasing urbanization in Jabodetabek \\
\hline & The increase of daily traffic in Jabodetabek \\
\hline & The high congestion and low levels of security and safety in traffic \\
\hline & Environmental pollution \\
\hline & $\begin{array}{l}\text { The uncontrollable growth of facility and the backwardness of infrastructure } \\
\text { development }\end{array}$ \\
\hline & The deviation of land use \\
\hline & The subject matter of Jabodetabekjur spread in functional areas \\
\hline & institutional problems of ineffective cooperation \\
\hline \multirow{3}{*}{ Ends planning } & $\begin{array}{l}\text { The growth of private vehicles in urban areas has increased and the use of public } \\
\text { transport has decreased significantly }\end{array}$ \\
\hline & The increase of daily traffic in Jabodetabek \\
\hline & The high congestion and low levels of security and safety in traffic \\
\hline \multirow{5}{*}{ Means planning } & The development of productive regional economy \\
\hline & The sustainable environmental capacity \\
\hline & The integration of spatial planning between regions as a unified planning area \\
\hline & The coordination of planning and execution of development in Jabodetabek area \\
\hline & $\begin{array}{l}\text { The institutional revitalization in Jabodetabek transportation management } \\
\text { cooperation }\end{array}$ \\
\hline Resources planning & $\begin{array}{l}\text { Financial planning, operator, and management organization, including } \\
\text { partner organizations, the source of transportation policy settings, the use of } \\
\text { environmentally friendly technologies, the level of public knowledge }\end{array}$ \\
\hline \multirow{3}{*}{ Design of implementation } & $\begin{array}{l}\text { Government between cities/regions: Transportation Policy settings, monitoring the } \\
\text { implementation of the provision of means of transportation }\end{array}$ \\
\hline & $\begin{array}{l}\text { BKSP of Jabodetabek: to coordinate the planning and implementation of } \\
\text { development in Jabodetabek area }\end{array}$ \\
\hline & $\begin{array}{l}\text { Private Sector: operator of transportation network manager, the use of modern } \\
\text { technology }\end{array}$ \\
\hline Design of control & Monitoring and evaluation of the implementation planning \\
\hline
\end{tabular}

Source: Researcher's processing result, 2016, adapted from the data of Research and Development Agency of Transportation, 2015.

1. The growth of private vehicles in urban areas has increased and the use of public transport has decreased significantly

2. The increase of daily traffic in Jabodetabek

3. The high congestion and low levels of security and safety in traffic

The first and second points will be achieved if the gap to the problem of uncontrolled facility growth and backwardness of means of infrastructure development have been addressed and fulfilled. The control of facility and infrastructure growth will encourage a reduction in the use of a private vehicle if the quality and facility of infrastructure and the procurement of infrastructure provided are satisfactory.

Meanwhile, gaps related to traffic congestion and security arise or rooted from the indiscipline of vehicles users in traffic and the excessive procurement of transportation and use of private vehicles. Therefore, when the gaps in the issues of first and second points are resolved, then it will automatically address the gaps related to this congestion problem. Thus, the gap in the case of high congestion problems and the low level of traffic 
security and safety are also included in gaps related to the availability of facilities and procurement of infrastructure.

With the reduction of gaps that can be incorporated into the issue or another gap, then means planning can be conducted for the procurement of sustainable transportation with the participation of various parties, both from the government of Jabodetabek for innovative coordination and cooperation as well as other parties, including academics, NGOs, and communities. This participation is very important to support the successful achievement of the management of sustainable transportation procurement so that various existing problems can be solved. Means planning in achieving effective and efficient transportation service is carried out by planning the programs or projects and measures taken to reduce or overcome the gaps in the procurement of transportation in Jabodetabek. It is based on the principles of participation, continuity and holistic.

Below are several actions or programs in applying means planning.

1) Productive Regional Economic Development

Through cooperation between regions in Jabodetabek, then it will bring in good investment both from the private sector and state-owned enterprises to manage transportation facility and infrastructure that are environmentally friendly. With this investment, the economy of the region will also increase.

\section{2) Creating Sustainable Environment Capacity}

The procurement of means of transportation should be done in a sustainable manner by taking into account social, economic and environmental aspects. The procurement of these facilities should be utilized until the next generation by not polluting the environment (principle of continuity), such as air pollution. Therefore, environmentally friendly fuel is necessary for the procurement of public transportation facility that will be made. This will encourage the existence of cooperation among various parties, and the role of a leader in guiding the society to welfare in the form of positive mindset and make big and innovative changes can affect the achievement of the maximum result (holistic principle).

3) The Integration of Spatial Planning Across the Regions as a Whole Planning Area.

Thus, the government must open up and engage in understanding the condition of the problem that is happening continuously. This is because the interrelationship between one and the other components in the procurement of means of transport is interlinked and continuous (holistic principle)

4) Coordinating the planning and implementation of development in Jabodetabek area
Coordination is essential and needs to be done among the local governments in Jabodetabek so that there is a conformity of interest in the management of environmentally friendly transportation. Through coordination, the division of tasks in solving existing problems in a particular area becomes easier.

5) Institutional revitalization of transportation cooperation in Jabodetabek

The existence of institutions that already exist in the cooperation between regions in Jabodetabek such as Jabodetabek BKSP is very important to be reevaluated to revitalize the role of these institutions so as to give more functionality and benefits to members.

After several programs have been created and specific strategies are compiled, then next is to see resources in Jabodetabek whether they are sufficient for the implementation of various programs and projects, both in terms of financial, human resources, the use of technology level, regulation, and knowledge society of level (resources planning ). If the resources owned are known then the next stage is to implement projects and programs that have been compiled by categorizing the implementers of the program (design of implementation), as follows:

1. Government between cities/regions: The setting of transportation policy, monitoring the implementation of means of transportation procurement, coordination between city governments in Jabodetabek.

a. The setting of transportation policy

Transportation policy in Jabodetabek can be applied through a forum of traffic and transportation in which under Article 13 of the new Law on traffic and transportation, indicating the formation of traffic and transportation "forum", with the main task to coordinate between the relevant institutions in planning, problem analysis, and seeking solutions to the efforts in creating better traffic and transportation services. This forum could be established within the framework of the governance structure at the levels of provincial and city/district in Jabodetabek. Each forum is divided not only based on government administrative structures but also based on the classification of the road. The Forum is structured in such a way because this institution requires a management that is specific to road administration that does have different coverage, rather than considering the road and transportation as one of many factors the same area, both urban and rural. In addition to these facts, the forum is also more oriented as a coordinating body for government agencies (JICA and ALMEC, 2012).

To harmonize the development of spatial planning of Jabodetabek, needed 
a transportation system that is effective, efficient and integrated. The system can be implemented through RUJAM (General Plan of Mass Transportation Network) in Jabodetabek Urban Area in which based on the Report of the Research and Development of Transportation (2015) is intended to:

- Make the service and procurement of public transportation the backbone of transportation in Jabodetabek

» Has a quality of service that is fast, secure, unified, orderly, smooth and comfortable

» Reaching out to all the needs of society with the characteristics: economical, efficient, effective, and affordable to people's purchasing power.

- Decrease the dependence on the use of private vehicle

- Increase the integration between mode and inter mode

- Build the pattern of "push" and"pull" through the establishment of transportation demand management.

Meanwhile, through the Regulation of the Minister of Transportation No. 54/2013, has also been set the direction of mass transportation development in Jabodetabek, namely:

- The development of integrated road and rail mass transportation networks

- The development of infrastructure / facilities to support mass transportation according to the standard of SPM (minimum service standards)

- The utilization of the development of increasingly sophisticated technological improvement

- The development of environmentally friendly mass transportation.

Jabodetabek mass transportation development priority as set out in the development priority, based on the stage: a) short-term, b) medium-term, and c) the longterm.

b. Supervision on the Implementation of Transportation Facility Procurement

Supervision may be made by the Jabodetabek Transportation Authority (OTJ) in which the main tasks of OTJ are: 1) to formulate short-term measures planning based on transportation master plan, 2) to improve public transport services and develop important supporting infrastructure, 3) to implement traffic demand management, 4) to promote transit-oriented development, 5) to finance and carry out the planning and monitoring of its performance (JICA and ALMEC, 2012).

c. Coordination between City Governments in Jabodetabekpunjur

The coordination between the governments in Jabodetabek requires an institution that embodies Jabodetabek intergovernmental forums such as traffic and transportation forum. In this case, BKSP of Jabodetabekpunjur is an existing institution and needs to continue to run with the authority to fix the authority in the institutional body that can accommodate the traffic and transportation forum in Jabodetabekpunjur.

2. BKSP ofJabodetabek: to coordinate the planning and implementation of the development in Jabodetabek area, including coordination with the Department of Transportation: transportation facility management, and financial management based on the number of transportation services procurement, as well as the dissemination of the use of public transportation to the public.

The institutions that deal with this Jabodetabekpunjur region should be able to perform the functions of coordination, integration, synchronization, and simplification optimally, and become the representation of the regions in consultation with the Central Government, covering all aspects of the cooperated development in the region of Jabodetabekpunjur. In the horizontal position, the institution should have the authority that binds the parties together through a specific regulation with the imposition of sanctions for members who do not abide by the decisions set forth together in the meeting of Jabodetabekpunjur BKSP. This authority is centralized in BKSP of Jabodetabekpunjur and not separately in each regional government of Jabodetabekpunjur. Therefore, the stakeholders in the region should be able to unite their perceptions, interests and priorities in Jabodetabekpunjur area joint development, by providing the support of ideas, funding, and adequate human resources for the shared interest (Secretary of BKSP, 2008: 34).

Based on the Decree of the Minister of Home Affairs No 29 of 1980 the Decree of the Minister of Bappenas No 125 of 1984, the main duties and functions of BKSP are: (1) the implementation of the policy formulation of Jabodetabekjur joint development, (2) the implementation of Jabodetabekjur joint 
development program preparation, (3) the implementation of Jabodetabekjur joint development, and (4) the evaluation of Jabodetabekjur joint development program. BKSP was formed to create an integration, synchronization, harmony, and balance on the implementation of development in Jabodetabekjur (Research and Development Agency of Transportation, 2015).

The purpose is to coordinate better planning, implementation, and monitoring of development in the region. Meanwhile, the membership of BKSP is all provincial and district/city governments located in Jabodetabek (Rustiadi, 2007), led jointly by the Governors of DKI Jakarta, West Java, and Banten, while the daily implementation is held by an executive secretary who is appointed by the leaders of this institution for a period of five years in rotation. The scope of cooperation of BKSP in the Report Research and Development Agency of Transportation (2015) is as follows:

a. spatial planning,

b. residential, facility, and infrastructure,

c. water resources, sanitation, and environment,

d. transportation, communications and tourism,

e. agribusiness, cooperatives, and small and medium enterprises,

f. industry, trade, mining, and investment,

g. population, tranquility and order,

h. health and education,

i. social and manpower

3. Private: as the operator of transportation network manager in cooperation with the transportation department in order to provide a service that can give satisfaction to the public in accordance with transportation quality assurance being offered, namely through modern technology and environmentally friendly, such as Bus Rapid Transit (BRT), monorail, procurement of trains network, and so forth.

A model of cooperation that can be done by the private sector, for instance, is through services operations and maintenance contracts where the assets owned by the government can be operated or treated by private parties with certain service standards or with the outsourcing of operation or maintenance. In this case, the asset ownership remains or is held by the government and the private sector is only authorized in the operations, maintenance, and transportation service contracts in Jabodetabek within a certain period, usually in the short term of 1-3 years
(Raharjanto, 2011: 28). Meanwhile, another model that can be applied in cooperation with the private sector is through concessions if it wants to cooperate in the long term which is about 10-20 years. Concessions made private operators fully responsible for services in certain areas, including operations, maintenance, management, development and rehabilitation of the system and is responsible for all capital investment. Although in that case the assets remain with the public even during the concession period so that in this case the government is responsible for setting performance standards and ensure the fulfillment of the concession (Raharjanto, 2011: 32-33).

The final stage to be implemented in interactive planning model is the design of control on the implementation of policies and programs that have been set. When a program does not work, then identified the cause of the problem or evaluated later to seek the best replacement solution to run the program (the principle of continuity). This is done by involving the role of leader and followers, both from the government officials, the private sector, and community (participative and holistic principle). Another controlling is done towards the budgeted finance for conducting a provision of public transportation means, whether it is efficient or not.

Various stages above are implemented by their interconnectedness and interdependence between one to the other stages. The running of stages in interactive planning methods is heavily dependent on the inter-city cooperation of Jabodetabek. Namely in establishing interagency cooperation as well as other sectors and involving community participation so that found the solution related to various issues such as the overlapping of authority as well as the ineffectiveness of existing cooperation agencies as well as the idea of managing the provision of more innovative sustainable transportation.

The transportation management cooperation is expected to provide benefits for all parties. As mentioned by Pratikno, et al (2004) that the cooperation between regions can provide several benefits as follows.

a. Management of conflict between regions, where cooperation between regions in Jabodetabek can be a forum for communication and dialogue among the main regional actors. With the existence of such a forum, it can enhance the understanding of the problems and people's needs in each region of Jabodetabek. 
b. Service Efficiency and Standardization, where cooperation between regions in Jabodetabek, especially in the management of the provision of sustainable transportation, will benefit the Jabodetabek government to establish cooperative actions to handle the existing problems. Thus, public service turned out to be better and more efficient.

c. Economic Development, where cooperation between regions in Jabodetabek will promote economic development that will enhance the competitiveness of the region. It often happens that the economic development of a region is hampered due to the limited area scope. As it has been known that Jakarta as the central administration of the State of Indonesia has given attraction of the regions around Jakarta, such as Bogor, Depok, Tangerang and Bekasi, where each region has different characters.

d. Environmental Management, where cooperation between regions in Jabodetabek in the management of sustainable transportation encourage shared environmental management on the main issues such as air pollution and environmental pollution. Without such cooperation, environmental management will not run synergistic and is potential of causing environmental problems, not only in the region, but also for other regions that are geographically close, such as forest fires, floods, and landslides.

\section{Conclusion}

The management of sustainable transport, especially in Jabodetabek needs to be done jointly in an institutional or policy framework involving Jabodetabekpunjur governments, BKSP of Jabodetabekpunjur, and the private sector. This is because the problems that exist in the Jabodetabek is a shared responsibility that requires cooperation in addressing the problems of transportation. Seeing the problems that exist both concerning the management of transportation and the existence of Jabodedatbek institutional cooperation that already exist, namely BKSP of Jabodetabekpunjur, then things that must be addressed are as follows.

1. Synchronizing the issues of transportation policy settlement

2. Repairing and fixing the issues of BKSP Jabodetabekpunjur institutional functions which before were confused between the policy basis with structural implementation consequences and the product of nonstructural policy.

3. Fixing the authority of BKSP Jabodetabekpunjur so as to bind its members.

4. Concerning the issue of financing and transportation management can be done through cooperation with the private sector through a contract of service and maintenance models or other forms which still prioritizing ownership of assets in the hands of the public or the government.

Thecooperationinitiatedbetweengovernments in Jabodetabekpunjur will provide conveniences in overcoming the existing problems related to the management of sustainable transportation including in managing conflicts between regions in Jabodetabek on who should be responsible for the problems of the chaotic spatial in the region thereby affecting the governance systems of transportation. This interregional cooperation will also be able to provide economic benefits and address the problems of transportation modes, especially in the province of West Java that is still minimal or far from decent conditions. Moreover, cooperation in the provision of sustainable transport by promoting environmentally friendly energy efficiency will reduce the impact on the environment especially related to emissions released from transportation activities.

\section{REFERENCES}

Abdurahman, B. (2008). Urgensi Revitalisasi Pengelolaan Jabodetabekjur. Jakarta: LEKAD.

Ackoff, R. (2001). A Brief Guide to Interactive Planning and Idealized Design. Lancaster.

Anderson, W. (1960). Intergovernmental Relations in Review. Minneapolis: University of Minnesota Press.

Ansell, C. \& Gash, A. (2007). Collaborative Governance in Theory and Practice. Journal of Public Administration Research And Theory, 18(4), 543-571. http://dx.doi.org/10.1093/ jopart/mum 032

Bingham, L. \& O'Leary, R. (2006). Conclusion: Parallel Play, Not Collaboration: Missing Questions, Missing Connections. Public Administration Review, 66(s1), 161-167. http://dx.doi. org/10.1111/j.1540-6210.2006.00686.x

Black, W. (2010). Sustainable Transportation: Problems and Solutions.. New York: Guilford Press.

Buehler, R. \& Pucher, J. (2011). Making public transport financially sustainable. Transport Policy, 18(1), 126-138. http://dx.doi. org/10.1016/j.tranpol.2010.07.002

Directorate General of Land Transportation, Ministry of Transportation, The Republic of Indonesia,. (2012). Project for the Study on Jabodetabek Public Transportation Policy Implementation Strategy in the Republic 
of Indonesia (JAPTraPIS). Jakarta: Japan International Corporation Agency (JICA) and ALMEC Corporation Oriental Consultants Co., Ltd.

Feiock, R. (2004). Metropolitan Governance: Conflict, Competition and Cooperation. Washington D.C.: Gorgetown University Press.

Feiock, R. (2007). Rational Choice and Regional Governance. Journal of Urban Affairs, 29(1), 47-63. http://dx.doi.org/10.1111/j.14679906.2007.00322.x

Gudmundsson, H. \& Höjer, M. (1996). Sustainable development principles and their implications for transport. Ecological Economics, 19(3), 269-282. http://dx.doi.org/10.1016/s09218009(96)00045-6

Gwilliam, K. (2002). Cities on the Move: a World Bank Urban Transport Strategy Review. Washington D.C.: World Bank.

Kahn Ribeiro, S., Kobayashi, S., Beuthe, M., Gasca, J., Greene, D., \& Lee, D. et al. (2007). Transport and Its Infrastructure. In B. Metz, O. Davidson, P. Bosch, R. Dave \& L. Meyer, Climate Change 2007: Mitigation. Contribution of Working Group III to the Fourth Assessment Report of the Intergovernmental Panel on Climate Change. Cambridge: Cambridge University Press.

Keast, R., Brown, K., \& Mandell, M. (2007). Getting The Right Mix: Unpacking Integration Meanings and Strategies. International Public Management Journal, 10(1), 9-33. http:// dx.doi.org/10.1080/10967490601185716

Kerjasama Antardaerah dalam Penataan Ruang Kawasan Jabodetabekpunjur. (2008). Buletin Tata Ruang.

Litman, T. \& Burwell, D. (2006). Issues in sustainable transportation. International Journal of Global Environmental Issues, 6(4), 331. http://dx.doi. org/10.1504/ijgenvi.2006.010889

Lumbo, D. (2007). Applications of Interactive Planning Methodology (Master Thesis). University of Pennsylvania.
Mansyur, U. (2008). Model Pengelolaan Transportasi Angkutan Umum Penumpang Non-bus Berkelanjutan Kota Makassar (Dissertation). Institut Pertanian Bogor.

Mungkasa, O. (2012). Pembangunan Perumahan pada Penerapan Model 'Compact City' di DKI Jakarta. Buletin Tata Ruang Dan Pertanahan Tahun 2012.

Nawawi, H. \& Martina,. (1994). Metode Penelitian Bidang Sosial. Yogyakarta: Gadjah Mada University Press.

Pratikno,. (2016). Mengelola Dinamika Politik dan Sumberdaya Daerah. Yogyakarta: PLOD Departemen Dalam Negeri.

Raharjanto, Y. (2011). Model of Public-Private Partnership in Jabodetabek Railways Capacity Enhancement (Master Thesis). Universitas Indonesia.

Raharjo, B. (2009). Model Kelembagaan dari Kerjasama Antar Daerah di Jabodetabek (Master Thesis). Universitas Indonesia.

Rencana Induk Transportasi Jabodetabek.. (2015). Jakarta.

Rustiadi, E. (2007). Analisis Spasial Permasalahan Pembangunan Kawasan Jabodetabek. Presentation, Institut Pertanian Bogor.

Ruyani, M. (2011). Perkembangan Badan Kerjasama Pembangunan (BKSP) Jabodetabekjur. Presentation, Ministry of Home Affairs.

Sakamoto, K., Belka, Stefan, \& Metschies, G. (2011). Pembiayaan Transportasi Perkotaan yang Berkelanjutan. Eschborn: Deutsche Gesellschaft für Internationale Zusammenarbeit (GIZ).

Supported NAMA Program Transportasi Perkotaan Berkelanjutan Indonesia/Sustainable Urban Transport Programme Indonesia (SUTRI NAMA) Fase Percontohan. (2014). Jakarta.

Tarigan, A. (2009). Meningkatkan Daya Saing Wilayah. Buletin Tata Ruang.

World Health Organization,. (2004). World Report on Road Traffic Injury Prevention. Geneva: World Health Organization. 